Published in final edited form as:

ACS Infect Dis. 2016 June 10; 2(6): 382-392. doi:10.1021/acsinfecdis.6b00041.

\title{
Therapeutic Potential of Spirooxindoles as Antiviral Agents
}

\author{
Na Ye ${ }^{\dagger}$, Haiying Chen ${ }^{\dagger}$, Eric A. Wold ${ }^{\dagger}$, Pei-Yong Shi ${ }^{\dagger, \ddagger, \#, ~ a n d ~ J i a ~ Z h o u ~}{ }^{\dagger, \perp, *}$ \\ ${ }^{\dagger}$ Chemical Biology Program, Department of Pharmacology and Toxicology, University of Texas \\ Medical Branch, 301 University Boulevard, Galveston, Texas 77555, United States \\ ‡Department of Biochemistry \& Molecular Biology, University of Texas Medical Branch, 301 \\ University Boulevard, Galveston, Texas 77555, United States \\ \#Sealy Center for Structural Biology \& Molecular Biophysics, University of Texas Medical Branch, \\ 301 University Boulevard, Galveston, Texas 77555, United States \\ ${ }^{\perp}$ Center for Biodefense and Emerging Infectious Diseases, University of Texas Medical Branch, \\ 301 University Boulevard, Galveston, Texas 77555, United States
}

\begin{abstract}
Antiviral therapeutics with profiles of high potency, low resistance, panserotype, and low toxicity remain challenging, and obtaining such agents continues to be an active area of therapeutic development. Due to their unique three-dimensional structural features, spirooxindoles have been identified as privileged chemotypes for antiviral drug development. Among them, spiropyrazolopyridone oxindoles have been recently reported as potent inhibitors of dengue virus NS4B, leading to the discovery of an orally bioavailable preclinical candidate $(R)-\mathbf{4 4}$ with excellent in vivo efficacy in a dengue viremia mouse model. This review highlights recent advances in the development of biologically active spirooxindoles for their antiviral potential, primarily focusing on the structure-activity relationships (SARs) and modes of action, as well as future directions to achieve more potent analogues toward a viable antiviral therapy.
\end{abstract}

\section{Graphical abstract}

*Corresponding Author: (J.Z.) jizhou@utmb.edu. Phone: (409) 772-9748.

Notes

The authors declare no competing financial interest. 


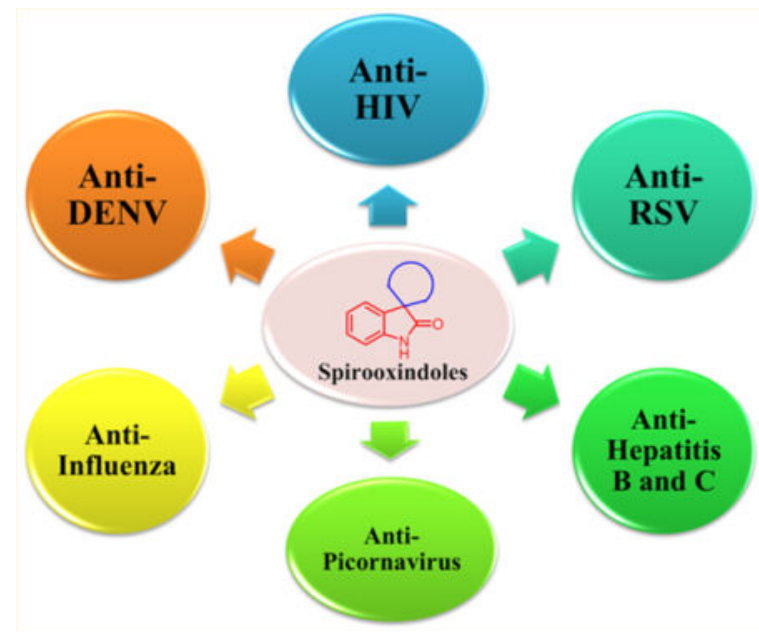

\section{Keywords}

spirooxindoles; antiviral agents; HIV; RSV; DENV; influenza virus

Over the past two decades, remarkable progress has been made toward the discovery and development of antiviral agents that could selectively inhibit viruses without causing toxicity. These antiviral agents inhibit the viral infection cycle through distinct mechanisms, including blocking the synthesis of viral proteins and nucleic acids, receptor recognition, entry, uncoating, virion assembly, and maturation. ${ }^{1,2}$ A number of effective antiviral agents are now available in the market. Such success is exemplified by more than 30 clinically approved anti- AIDS drugs. ${ }^{3}$ However, the options for available antiviral chemical space, including the diversity of chemical entities and new scaffolds, remain limited and effective against only a small group of pathogens, including human immunodeficiency virus (HIV), herpes simplex virus (HSV), varicella-zoster virus (VZV), human cytomegalovirus (HCMV), influenza virus, and hepatitis B and C viruses (HBV and HCV, respectively). ${ }^{4}$ Moreover, these drugs are plagued by the increasing emergence of drug resistance, limited therapeutic efficacy, and severe drug side effects. ${ }^{1,5,6}$ Additionally, for many other emerging and/or neglected life-threatening viral diseases (e.g., dengue fever and Zika virus), the lack of approved medications for clinical use represents an unmet medical need. ${ }^{7}$ Hence, it is imperative to develop antiviral agents with novel chemotypes, antiresistance, panserotype activity, high efficacy, and low toxicity profiles, as well as increased affordability.

Spirocyclic compounds are notable for their unique three-dimensional structures as well as their broad biological activity. ${ }^{8}$ In particular, spirocyclic oxindoles characterized by varied spiro rings fused at the $\mathrm{C} 3$ position of the oxindole core represent privileged scaffolds with prevalence in numerous natural products (e.g., 1-4, Figure 1) and pharmacologically relevant drugs (e.g., 5-10, Figure 1) ${ }^{8-10}$ Their conformational restriction, imparted by the spiro-carbon, provides an excellent strategy to not only enforce the desired conformation for ligand-protein binding to enforce specificity and potency but also potentially increase molecular complexity to reduce P450 inhibition for better bioavailability and metabolic stability. ${ }^{11,12}$ Moreover, owing to the synthetic challenges associated with this unique 
structure, there have been notable synthetic methodology advancements ${ }^{13-15}$ that have provided a means by which spirooxindoles can be pursued as candidates for drug discovery. Although a number of spirooxindoles have been reported with different biological activities, fortunately, this class of molecules is not promiscuous such as those troublesome pan-assay interference compounds (PAINS). ${ }^{16-19}$ Actually, some of them (e.g., compound $\mathbf{4 4}$ discussed later on) have been identified to be quite target-specific. To the best of our knowledge, the various bioactivities of spirooxindoles are primarily distinguished by the pattern and size of the spiro rings fused at the $\mathrm{C} 3$ position of the oxindole scaffold as well as specific substituent moieties on the spirocyclic oxindole core, thereby leading to the diverse but relatively specific pharmacological profiles of this class of molecules.

By using structure-based drug design and computational docking, natural alkaloids such as spirotryprostatin A (1) and alstonisine (2) were found to fit poorly into the mouse double minute 2 homologue (MDM2) protein cleft due to steric hindrance. ${ }^{20}$ Thus, further structural simplification led to the identification of spiro-pyrrolidinyl MI-888 (5) as a potent nonpeptide inhibitor of p53/MDM2 interaction $\left(K_{\mathrm{i}}=0.44 \mathrm{nM}\right)$, which was reported to achieve rapid, complete, and long-lasting tumor regression in two types of xenograft models of human cancer, with oral administration. ${ }^{21}$ Spiro-cyclohexyl satavaptan (6) was designed by Sanofi-Aventis and is a vasopressin-2 receptor antagonist under development for the treatment of hyponatremia ${ }^{22}$ and ascites. ${ }^{23}$ Spiro-tetrahydro- $\beta$-carboline NITD609 (7) is a synthetic antimalarial drug, an alternative to artemisinin derivatives, and eliminates the blood stages of Plasmodium falciparum and Plasmodium vivax clinical isolates at a low nanomolar concentration by inhibiting protein synthesis. ${ }^{24}$ Given its good physicochemical properties and promising pharmacokinetic and efficacy profile, compound 7 has recently completed phase II studies in humans (NCT01860989; NCT01836458; NCT01524341). Spiro-thiazolidinyl cruciferous phytoalexin spirobrassinin (3) was found to have an antiproliferative effect against T-Jurkat leukemic cells, ${ }^{25}$ whereas a similar synthetic framework, $\mathbf{8}$, was identified as a potent $5-\mathrm{HT}_{6}$ antagonist after the introduction of benzazepine fragments. ${ }^{26}$ Likewise, antifungal (+)-welwitindolinone A (4) is a densely functionalized and compact spirofused cyclobutyl oxindole alkaloid that was isolated from the marine blue-green algae Hapalosiphon welwitschii to overcome multiple drug resistance, ${ }^{27}$ whereas its simplified analogue 9 is a potent and selective p38 $a$ mitogenactivated protein (MAP) kinase inhibitor and functions as a novel anti-inflammatory agent. ${ }^{28}$ In addition, spirocylic oxindoles such as spirocyclopropyl $\mathbf{1 0}$ were reported to have therapeutic value for obesity, diabetes, and gastrointestinal and urinary diseases, functioning via a $\beta_{3}$ adrenoceptor agonism. ${ }^{29}$

Intriguingly, spirooxindoles have attracted much attention in the area of antiviral drug discovery and development in recent years, owing to the high number of positive hits encountered with this scaffold. Herein, we seek to review the current progress of spirooxindoles in the antiviral drug research field, including human immunodeficiency virus (HIV), human respiratory syncytial virus (RSV), dengue (DENV), and influenza virus. 


\section{ANTI-HIV AGENTS}

HIV is a retrovirus that infects cells of the immune system, destroying or impairing their function. The most advanced stage of HIV infection is acquired immunodeficiency syndrome (AIDS), which is a global health threat and the leading cause of death due to infectious diseases by a single infectious agent. Since the beginning of the epidemic in 1981, almost 78 million people have been infected with the HIV virus and nearly 39 million people have died from HIV. ${ }^{30}$ Combination anti-retroviral therapy (cART), especially oncedaily fixed-dose combination (FDC) such as Abacavir/Lamivudine, Atazanavir/Cobicistat, and Darunavir/Cobicistat, ${ }^{31-33}$ is the current standard of care regimen for AIDS patients and has led to a significant halt in the progression of AIDS and a decline of the mortality rates. ${ }^{34,35}$ Nevertheless, the side-effect profile and the prevalence of drug resistance during long-term therapy may cause treatment failure. ${ }^{36}$

Many efforts have been made to develop new inhibitors specifically to overcome drug resistance problems that occur during the treatment of AIDS. Given that oxindoles currently utilized in several FDA-approved drugs may also interact and fill the $\mathrm{P}_{2}{ }^{\prime}$ region of HIV protease active site effectively, Ghosh et al. ${ }^{37}$ designed and synthesized novel oxindolederived inhibitors with the aid of a high-resolution X-ray crystal structure of the HIV protease with Darunavir (11, Figure 2). This work resulted in a second-generation protease inhibitor approved by the FDA on June 23, 2006, to combat mutant strains of HIV. Oxindoles 12a and 12b have shown antiviral potencies of 6 and $3 \mathrm{nM}$, respectively, with only a slight difference between the two diastereomers. Considering that constrained rings in the HIV protease active site significantly improved enzyme inhibitory activity, ${ }^{38-40}$ the feasibility of spirocyclic oxindole derivatives as $\mathrm{P}_{2}{ }^{\prime}$-ligands has also been examined. Unfortunately, there was a dramatic reduction in inhibitory potency for the corresponding six- and seven-membered unsaturated and saturated spirocyclic compounds, such as 13-16. The basis for this potency loss was revealed by docking that showed oxindole carbonyls of the spirocyclic derivatives do not overlap with the sulfone oxygen of $\mathbf{1 1}$ that effectively interacts with the tightly bound water molecule in the active site. ${ }^{37}$

Non-nucleoside reverse transcriptase inhibitors have been viewed as therapeutic agents with the potential to solve drug resistance problems. Using a cell-based HIV reporter infection screening assay, hit 17, an oxindole with a unique spiral cyclopropane moiety (Figure 3), was identified as an HIV reverse transcriptase inhibitor with an $\mathrm{EC}_{50}$ value of $\sim 75 \mathrm{nM}^{41}$ The relative stereochemistry around the cyclopropane moiety, confirmed during a later synthesis, was found to be crucial for its antiviral activity due to its specific interactions with reverse transcriptase. ${ }^{41}$ Systematic structural modifications have been conducted to establish preliminary SAR, including multiple substituents on the aromatic ring and various substituents on the cyclopropane, the lactam moiety, and the ester group, leading to the discovery of the early lead compound $\mathbf{1 8}$ with a gem-dimethyl on the cyclopropane. ${ }^{41}$ Although lead 18 displayed significantly improved potency with an $\mathrm{EC}_{50}$ of $15 \mathrm{nM}$, it unfortunately exhibited high clearance, low exposure, and limited oral bioavailability ( $F=$ $27 \%$ ), possibly associated with its poor rat liver microsomal stability in vitro. ${ }^{42}$ Considering that the ester moieties may be the cause of its metabolic instability, further efforts to replace them with bioisosteres, including tetrazole, furan, thiophene, pyrrole, thiazole, imidazole, 
pyridine, and phenyl and biaryl rings, have been carried out. 2-Pyridinyl analogue 19 exhibits a surprisingly potent inhibition of HIV replication, with an $\mathrm{EC}_{50}$ of $8 \mathrm{nM}$. As expected, 19 has enhanced water solubility and metabolic stability in vitro, as well as improved pharmacokinetic properties in vivo, with an $F$ value of $46 \%$. Although it was reported to have antiviral activity against L100I, I135T, I135V, E138K, and F227L mutant viruses, poor antiviral activity was found against K103N, Y188C, and Y188L. ${ }^{42}$ Further optimization would be required to achieve potency in all NNRTI-resistant mutant viruses.

In addition, viral protein $\mathrm{R}(\mathrm{Vpr})$, a small protein encoded in the central region of the HIV-1 genome, is also an ideal target for inhibiting HIV-1 replication due to its unique functions in nuclear import, ${ }^{43}$ induction of cell cycle arrest at the $\mathrm{G} 2$ phase, ${ }^{43}$ apoptosis regulation, ${ }^{43-45}$ and splicing inhibition. ${ }^{46}$ Aida et al.$^{47}$ developed novel chemical arrays as a useful method to screen compounds that bound recombinant Vpr purified from transfected COS-7 cells. Among these compounds, spirooxindole SIP-1 (20, Figure 3) was shown to significantly inhibit $\mathrm{Vpr}$ function via binding to its functional domain, thereby displaying high inhibitory activity against $\mathrm{HIV}$ with an $\mathrm{IC}_{50}$ of $0.5 \mu \mathrm{M}$ and reducing the levels of p24 by $>98 \%$ in macrophages after 8 or 12 days of infection. ${ }^{47}$ Moreover, $\mathbf{2 0}$ has no cytotoxic effects and does not disrupt cell cycle progression or induce apoptosis of Molt- 4 and HeLa cell lines as was measured by the MTT assay, flow cytometry analysis, and a caspase- 3 assay.

\section{ANTI-RSV AGENTS}

RSV is a large RNA virus and a member of the Paramyxoviridae family, subfamily Pneumoviridae. It is a major cause of respiratory tract infections in people of all ages worldwide. Because natural human immunity against RSV is incomplete, nearly every child has been infected by RSV at least once before the age of 3. Severe exposures to RSV can cause infection in normal adults and older children, largely upper respiratory tract infections, often leading to bronchiolitis and pneumonia that may require hospitalization. However, exposure to RSV at a young age may cause predominately lower respiratory tract infections, leading to recurrent wheezing and asthma.

There are limited effective treatment options against RSA infection for the above-mentioned patient populations. RespiGam (RSV-IG) ${ }^{48}$ and Synagis (palivizumab), ${ }^{49}$ developed by MedImmune (CA, USA), are a polyclonal-concentrated RSV neutralizing antibody and a humanized monoclonal antibody against RSV fusion (F) protein, respectively, and are intended for prevention and treatment in preterm and high-risk infants. However, both are very costly, leading to low affordability, and require parenteral administration.

Unfortunately, a newer version monoclonal antibody, motavizumab, failed to show additional benefit over palivizumab in recent phase III human clinical trials. ${ }^{50}$ Moreover, there is no RSV vaccine available for human use, despite many attempts in subunit vaccine and live-attenuated vaccine approaches. ${ }^{51}$ The fate of RNAi therapeutics against RSA such as ALN-RSV01 is still pending and relies on the result of phase II clinical trial. ${ }^{52}$

Virazole (ribavirin), a nucleoside analogue, is the only approved antiviral drug as an aerosol treatment of serious RSV infection in hospitalized children. Due to its aerosol administration, low affordability, limited efficacy, and toxicity profile (e.g., teratogenicity), it 
is rarely used in the clinic. Although a number of small-molecule RSV inhibitors have been discovered, only a few have reached phase I or II clinical trials, including the first nucleocapsid $(\mathrm{N})$ protein inhibitor RSV-604 developed by AstraZeneca. ${ }^{53}$

Nevertheless, safe and effective treatment of RSV disease is in urgent need. Direct-acting antivirals, specifically RSV fusion protein inhibitors, have been the focus of numerous drug development programs. ${ }^{54}$ BMS-433771 (21, Figure 4) is a benzimidazole-based representative RSV fusion inhibitor and has been reported to exhibit excellent potency in four mammalian species and efficacy in mouse and cotton rat infection models treated by oral administration. ${ }^{55}$ Mechanistic studies using a photo affinity probe have established that compound 21 interferes with the formation of the 6-helix bundle of the RSV F1 protein. This 6-helix bundle formation is an essential step in the fusion of virus and host cell membranes that occurs in the latter stages of the entry process. ${ }^{56} \mathbf{2 1}$ has thus attracted much attention from leading biopharmaceutical entities. Moreover, the recently resolved cocrystal structure of $\mathbf{2 1}$ with the assembled trimer of the N-terminal heptad repeat element of the RSV F1 protein ${ }^{57}$ has provided a tremendous opportunity to explore the molecular space and possibly discover novel scaffolds based on 21 (Figure 5).

Viral Ltd. ${ }^{58}$ first introduced the spiral exocyclic $N$-c-propyl group onto the 3-position of oxindole, which led to a novel series of compounds such as 22-24 with very weak activity $\left(\mathrm{EC}_{50}>80 \mu \mathrm{M}\right.$; Figure 5), likely due to the lack of hydroxyl group interacting with the viral protein. However, when the terminal hydroxyl group was reintroduced, inhibitory activity against RSV long strain was regained even if the benzimidazole was reduced to tetrahydrobenzimidazole (25). 25 displayed an $\mathrm{EC}_{50}$ value of $<0.1 \mu \mathrm{M}$ and a $\mathrm{CC}_{50}$ value of $>100 \mu \mathrm{M}$ in viral cytopathic effect (CPE) assays. ${ }^{59}$ When a methylsulfonyl group was further introduced to the terminal, Roche Ltd. ${ }^{60}$ identified compounds with activity and high potency against RSV long strain. Additionally, SAR studies showed that the 5-chloro on the benzimidazole gave the best activity. Further addition of a halogen atom onto the 4-position of the indolone fragment resulted in compounds 26-28, which display excellent inhibitory effects against RSV in the order $\mathrm{F}>\mathrm{Cl}>\mathrm{Br}$ (Figure 5), but all of them were less potent than the 6-aza-oxindole analogue $29\left(\mathrm{EC}_{50}=12 \mathrm{nM}\right)$. Replacement of the benzimidazole ring in 29 with an indole, by deleting a nitrogen atom, resulted in compounds 30, 34, and 35, with 2-4-fold enhanced $\mathrm{EC}_{50}$ values. However, modification of the benzimidazole ring in 29 into its structural isomers aza-indoles $\mathbf{3 1 - 3 3}$ led to a minor reduction in potency. A minor extension of the flexible methylsulfonyl linker length of $\mathbf{3 4}$ from two to three carbons (35) retained potency, with an $\mathrm{IC}_{50}$ value of $6 \mathrm{nM} .{ }^{60}$ Further studies indicated that inserting a pyridyl ring (36) as a structural constrained linker continued to retain potency, whereas the phenyl ring addition (37) led to a 5-fold decrease in potency. ${ }^{61}$ These findings suggest that the length and shape of the linker on a benzimidazole can be well scrutinized and optimized. Janssen Ltd. ${ }^{62}$ attempted to enlarge the spiro-cyclopropyl ring to a four to six-membered ring (38-42), including cyclobutyl, azetidyl, piperidyl, oxetyl, cyclopentyl, tetrahydro- $2 \mathrm{H}$ pyran, and tetrahydro- $2 H$-thiopyran 1,1-dioxide. Interestingly, compound 38 displayed a promising potency, with an $\mathrm{EC}_{50}$ value of $0.1 \mathrm{nM}$. In addition, replacement of the terminal methylsulfonyl (40) with a cyano group (41) was reported to improve potency by 79 -fold against rgRSV224 virus. 


\section{ANTI-DENV AGENTS}

Dengue is the fastest growing mosquito-borne viral disease, threatening roughly half of the world's population and causing nearly 400 million infections each year. ${ }^{63}$ Additionally, the incidence of dengue has increased 30 -fold over the past 50 years due to expanded urbanization, mobility of populations, and climate changes. ${ }^{64}$ There are currently several promising vaccine candidates in clinical trials, ${ }^{65}$ whereas the first vaccine, Dengvaxia, developed by Sanofi, was approved in Mexico on December 9, 2015, for the prevention of disease caused by all four dengue virus serotypes (DENV-1, DENV-2, DENV-3, and DENV-4) in patients 9-45 years of age living in endemic areas. ${ }^{66}$ For antiviral development, only repurposed compounds have been tested in dengue clinical trials, including the nucleoside inhibitor balapiravir, ${ }^{67} \mathrm{a}$-glucosidase inhibitor celgosivir, ${ }^{68}$ malaria drug chloroquine, ${ }^{69}$ corticosteroid drug prednisolone,${ }^{70}$ and lovastatin for lowing cholesterol level. ${ }^{71}$ However, none of them have shown significant antiviral activity or clinical benefits in dengue patients.

In an effort to develop safe and effective antiviral therapeutics, Wang et al. ${ }^{72}$ identified spiropyrazolopyridones as a novel chemical class of anti-DENV agents by utilizing a highthroughput phenotypic screening of the Novartis compound library. Hit 43 (Figure 6A) was shown to inhibit the DENV-2 replicon with an $\mathrm{EC}_{50}$ value of $14 \mathrm{nM}$. Because 43 is a racemate, two enantiomers were subsequently separated by chiral column HPLC and led to isolation of the $R$-enantiomer $(R)-\mathbf{4 3}$ with an $\mathrm{EC}_{50}$ value of $12 \mathrm{nM}$, which is 83 -fold more potent than the $S$-enantiomer. Further antiviral spectrum analysis of $(R)-\mathbf{4 3}$ against a panel of flaviviruses surprisingly revealed that $(R)-\mathbf{4 3}$ inhibits only DENV-2 and -3 , but not other viruses including DENV-1 and -4. Resistance analysis and direct ligand-protein binding confirmed that variations at amino acid 63 of DENV nonstructural protein 4B (NS4B), a nonenzymatic transmembrane protein functioning as an essential component of the viral replication complex, were responsible for the observed resistance in DENV-2 and -3 (Figure 6B) ${ }^{72}$ Thus, it confirms that $(R)-\mathbf{4 3}$ specifically targets DENV NS4B to block viral RNA synthesis or accumulation. Although $(R)-\mathbf{4 3}$ was found to be poorly soluble in aqueous media $(11 \mu \mathrm{M})$ and highly lipophilic with a $\operatorname{LogP}$ value of $4.9,(R)-43$ remains a promising starting point for lead optimization efforts in an attempt to improve the solubility while retaining or improving its potency. Utilizing a three-component condensation reaction of aminopyrazoles, commercially available isatin derivatives, and Meldrum's acid, Zou et al. quickly provided access to a series of spiropyrazolopyridone analogues for SAR investigation mainly focused on A-and B-ring modifications. ${ }^{73}$ It has been further confirmed by chiral column HPLC separation of racemates that $R$ enantiomers tend to be significantly more potent than $S$ enantiomers. Meanwhile, it has remained that both of the amide carbonyl groups appear to be important for the activity, whereas neither of the NH groups is critical for the potency. Cytotoxicity studies have indicated that these compounds portray advantageous toxicity selectivity for dengue-infected cells over normal cells.

Preliminary SAR studies following promising initial results have led to the discovery of a new chemical lead, $(R)-\mathbf{4 4}$ (Figure 6A). It is worth mentioning that $(R)-\mathbf{4 4}$ has been found to be quite target-specific in the exploration of off-target effects. Although $(R)-\mathbf{4 4}$ exhibited slightly decreased potency against DENV-2 in the secondary viral-titer reduction assay 
$\left(\mathrm{EC}_{50}=42 \mathrm{nM}\right)$, it possesses an enhanced aqueous solubility $(504 \mu \mathrm{M})$, an improved LogP value of 2.8 and a moderate mouse microsomal stability (hepatic extraction ratio $71 \% ; t_{1 / 2}$ $24 \mathrm{~min}$ ). These characteristics led to better in vivo pharmacokinetics with higher $C_{\max }$ and exposure (AUC) as well as increased oral bioavailability $(F=63 \%)$ in rats, when compared to those of compound $(R)-\mathbf{4 3}$. Furthermore, $(R)-\mathbf{4 4}$ demonstrates favorable in vivo efficacy in a DENV-2 viremia mouse model (Figure $6 \mathrm{C}$ ). When compound $(R)-\mathbf{4 4}$ was orally administered at $50 \mathrm{mg} / \mathrm{kg}$ twice daily (bid) for 3 days or orally dosed at $100 \mathrm{mg} / \mathrm{kg}$ once daily (QD) for 3 days, compared to vehicle control group, significant viremia reduction in mice was achieved. This result provides a valuable proof of concept that DENV NS4B protein is a valid and druggable antiviral target for dengue drug development.

After validation that DENV NS4B protein is a valid anti-DENV target, further modification was conducted by adding a nitrogen atom within a pyrazole ring and led to a new series of triazole analogues. ${ }^{74}$ Among these, compound 45 (Figure 6A) displayed the highest inhibitory activity against DENV-2 and DENV-3 in CFI assays with $\mathrm{EC}_{50}$ values of 14 and $2.5 \mathrm{nM}$, respectively, whereas three additional isomers showed moderate to low activity. Although the potency against DENV-3 nearly matches the DENV-2 activity, the major weakness of $(R)-\mathbf{4 3 - 4 5}$ is their lack of efficacy against other serotypes such as DENV-1 and -4 . Because the amino acid variation among the four DENV serotypes is $30-35 \%,{ }^{75}$ it will be a challenging but essential endeavor for medicinal chemists to achieve panserotype activity for successful drug development.

\section{ANTI-INFLUENZA VIRUS AGENTS}

Influenza virus is a prominent cause of upper respiratory tract infection disease and associated with high morbidity and mortality. In particular, China is considered an area with a high rate of influenza infection and influenza-associated morbidity. Globally, prevention and treatment of influenza currently relies on vaccines and fast-acting antiviral agents. In addition, traditional Chinese therapeutics have been used clinically for influenza therapy.

Isatis indigotica is a biennial herbaceous plant, and as a traditional Chinese medicine it has been used for the treatment of various ailments, especially influenza, cold, fever, and infections. ${ }^{76}$ A pair of enantiomers (46a and 46b; Figure 7) characterized by the $5^{\prime}, 6^{\prime}$ dihydrospiro[indoline-3,2' -thiopyran]-2-one and $3^{\prime \prime}$-( $2^{\prime \prime \prime}$-hydroxybut- $3^{\prime \prime \prime}$-en-1 $1^{\prime \prime \prime}$-yl)-1 $1^{\prime \prime}, 2^{\prime \prime}$, $4^{\prime \prime}$-thiadiazole moieties, which had never been presented in a natural product, was isolated by Chen et al. from aqueous extracts of the $I$. indigotica root. ${ }^{76}$ In vitro assays demonstrated ${ }^{77}$ that compounds $46 \mathbf{a}$ and $46 \mathbf{b}$ show similar antiviral activities against the herpes simplex virus 1 (HSV-1) with $\mathrm{IC}_{50}$ values of 33.33 and $25.87 \mu \mathrm{M}$ as well as SI values of 2.0 and 3.9, respectively. Compound 46a also inhibited the influenza virus A/Hanfang/ $359 / 95$ (H3N2), with $\mathrm{IC}_{50}$ and SI values of $33.33 \mu \mathrm{M}$ and 3.0, respectively, while 46b was found to be inactive $\left(\mathrm{IC}_{50}>100 \mu \mathrm{M}\right)$.

Strictosamide (47a) is a glycoalkaloid that has been isolated from leaves and roots of Sarcocephalus latifolius (Smith) Bruce (Nauclea latifolia Sm.), and it has been used as a medicinal plant in folk medicine due to its antiproliferative, antiparasitic, antimicrobial, antimalarial, anti-inflammatory, antiviral, and other suggested biological activities. ${ }^{78}$ 
However, the poor aqueous solubility, short half-life, and poor efficacy of strictosamide has limited its clinical application. Xu et al. has reported structural modifications that led to two series of strictosamide derivatives represented by $47 \mathrm{~b}$ and $47 \mathrm{c}$ and spirooxindoles $48 \mathrm{a}$ and $48 \mathrm{~b}$ that were synthesized by a rearrangement reaction of $47 \mathrm{c}$ under the treatment of $\mathrm{NBS} / \mathrm{H}_{2} \mathrm{O} / \mathrm{THF}$ (Figure 7). ${ }^{79}$ Compounds $47 \mathbf{b}$ and $47 \mathbf{c}$ were reported to possess high antiviral activities against influenza A virus (A/Jinan/15/90) with $\mathrm{IC}_{50}$ values of 4.12 and $12.35 \mu \mathrm{g} / \mathrm{mL}$, respectively $\left(\mathbf{4 7 a}: \mathrm{IC}_{50}=25.68 \mu \mathrm{g} / \mathrm{mL}\right)$. However, compounds $48 \mathbf{a}$ and $\mathbf{4 8 b}$ have shown very weak antiviral activity against influenza $A$ virus and respiratory syncytial virus $\left(\mathrm{IC}_{50}>110 \mu \mathrm{g} / \mathrm{mL}\right.$ ). Surprisingly, compounds $\mathbf{4 8 a}$ and $\mathbf{4 8 b}$ were revealed to have moderate antiproliferative effects against five human cancer cell lines (HepG2, A549, KB, MCF-7, and K562), with $\mathrm{IC}_{50}$ values in a range of 28.85-39.06 $\mu \mathrm{M}$.

To efficiently construct the spirooxindole core, Kurbatov et al. earlier designed a polar [3 +2 ] cycloaddition reaction of isatin, thiaproline, and arylidene derivatives of rhodanine to synthesize bis-spirocyclic compounds, such as $\mathbf{4 9}$, containing spiro units at the 1,2-positions of the pyrrolizidine (isothiapyrrolizidine) moiety (Figure 7). ${ }^{80}$ Later, the 1,3-dipolar addition reaction of unstabilized azomethine ylides generated in situ from isatin and proline (isothiaproline), with hetarylidene-substituted rhodanines, provided another novel bis-spiro heterocycle, such as 50, with spiro units at the 1,3-positions of the pyrrolizidine (isothiapyrrolizidine) moiety. Among these, compound $\mathbf{5 0}$ exhibited the most potent inhibitory activity against the influenza virus A/California/07/09(H1N1) -pdm2009 replication $\left(\mathrm{EC}_{50}=1.9 \mu \mathrm{g} / \mathrm{mL}\right)$ with high toxicity $\left(\mathrm{CTD}_{50}=37 \mu \mathrm{g} / \mathrm{mL}\right)$, whereas compound 49 showed the lowest toxicity $\left(\mathrm{CTD}_{50}=415 \mu \mathrm{g} / \mathrm{mL}\right)$ with moderate inhibition $\left(\mathrm{EC}_{50}=26.0\right.$ $\mu \mathrm{g} / \mathrm{mL}){ }^{80}$

\section{OTHER ANTIVIRAL AGENTS}

Picornaviruses represent a major health burden, yet antiviral treatments are not available. By using gene-trap mutagenized human haploid cells for screening picornaviral host-dependent factors, Burckstummer et al. found that human cells lacking PLA2G16, a poorly characterized phospholipase A2, are largely resistant to infection by all of the picornaviruses tested, including polio virus, coxsackie viruses, rhinoviruses, and encephalomyocarditis virus. However, those cells did not lose susceptibility to non-picornaviruses, such as vesivular stomatitis virus, influenza virus, adenovirus, and herpes simplex virus. ${ }^{81}$ To identify small-molecule inhibitors of PLA2G16 for combating picornavirus infection, a drug discovery program was subsequently initiated. This effort resulted in $25 \mu \mathrm{M}$ concentration, single-replicate screening of 24000 unrelated and highly diverse compounds, which originated from chemical diversity libraries (Otava and Enamine), focused libraries for kinases, chromatin modifiers, the NIH clinical collection, and others. Spirooxindoles $\mathbf{5 1}$ and 52 (Figure 7), identified from the aformentioned screen, were found to exhibit similar inhibitory activities against PLA2G16, with $\mathrm{IC}_{50}$ values of 7 and $6 \mu \mathrm{M}$, respectively. ${ }^{82}$ However, similar compounds such as the 4,4-disubstituted-1,4-dihydropyrimidines 53a and 53b, developed by Janssen R\&D Ireland, show weak anti-HBV activities using stable transfected cell lines HepG2.2.15 and HepG2.117 $\left(\mathrm{IC}_{50}>25 \mu \mathrm{M}\right){ }^{83}$ 
Hepatitis $\mathrm{C}$ virus (HCV) infects $>3 \%$ of the world's population, consequently leading to an increased risk of steatosis, cirrhosis, and hepatocellular carcinoma. HCV non-structural protein $5 \mathrm{~A}$ (NS5A) is a zinc-binding and proline-rich hydrophilic phosphoprotein that plays a key role in the virus replication cycle, facilitating both replication of the genomic RNA and assembly of the virion as well as modulating host cell factors to create an hospitable environment for the virus. ${ }^{84-86}$ With the successful discovery and the recent approval of Daclatasvir and Ledipasvir, ${ }^{87-89}$ NS5A inhibitors have emerged as a clinically relevant class of HCV therapeutic agents that may offer a promising replacement for the current standard of care, a combination of pegylated interferon alfa and ribavirin, which can be poorly tolerated and is often ineffective against the most prevalent genotype of the virus, genotype 1. ${ }^{90-94}$ Therefore, recent successes stimulate considerable interest in the design and development of NS5A inhibitors. Spirooxindoles as unique scalffolds have been used to replace the central biphenyl of Daclatasvir and the fluorene ring of Ledipasvir and have led to a novel series of NS5A inhibitors such as $\mathbf{5 4}$ and $\mathbf{5 5}$ with excellent $\mathrm{EC}_{50}$ values of 4.95 and $0.45 \mathrm{nM}$, respectively, against HCV1b genotype (Figure 7). ${ }^{95}$ Moreover, both analogues have also shown moderate potency against $\mathrm{HCV} 1 \mathrm{a}$ genotype $\left(\mathrm{EC}_{50}>400 \mathrm{nM}\right)$.

\section{CONCLUSIONS AND FUTURE DIRECTIONS}

Due to potential problems exhibited by current antiviral drugs including toxicity, mutagenicity, limited efficacy, poor bioavailability, racemization of chiral centers, and difficulty of synthesis, the search for a new generation of effective antiviral agents with better drug properties and affordability continues to be an active area of medicinal chemistry and antiviral research. Spirooxindoles have emerged as attractive scaffolds with unique structural architecture and noticeable biological activity.

Nevertheless, numerous reported spirooxindoles with structural novelty have not been evaluated for antiviral activity, which limits hit discovery for new antiviral agents. Considering that natural products have emerged as a great resource for the discovery of various therapeutic agents, ${ }^{96}$ structural modification on the template of oxindole alkaloids such as $46 \mathbf{a}$ and $\mathbf{4 6} \mathbf{b}$ and strictosamide (47a) may provide an alternative method to identify antiviral drug candidates with improved potency, aqueous solubility, and bioavailability. Moreover, although some spirooxindoles have previously been identified with antiviral activity, such as the DENV 4B inhibitors $(R)-\mathbf{4 3}$ and $(R)-\mathbf{4 4}$, their exact molecular target and mechanism of action remain to be elucidated, thereby increasing the difficulty for further rational drug design and discovery. Furthermore, many additional challenges based on currently available synthetic routes need to be addressed for further lead optimization, such as how to efficiently generate the pure enantiomers or diastereomers. Although chiral separation to yield pure enantiomers such as $\mathbf{2 0}$ and $(R)-\mathbf{4 3 - 4 5}$ is feasible in laboratories, applications in large-scale production or manufacturing could be costly and time-consuming.

Despite the exciting work and promising results on spirooxindoles as potential antiviral drugs as discussed above, challenges and opportunities remain for pharmacologists, medicinal chemists, virologists, and biologists to make synergistic efforts to eventually advance this class of molecules into a viable antiviral therapy. In terms of future directions, it is imperative to evaluate the antiviral activity of an expanded panel of spirooxindole-based 
chemical entities and to develop new methodologies, tool molecules, and biomarkers for elucidation of relevant molecular targets and exact mechanisms of action of active compounds. Meanwhile, there is an urgent need for structural biologists to resolve the X-ray crystallography of target-ligand complexes so as to facilitate rational antiviral drug design using modern drug discovery techniques such as structure-based drug design, ${ }^{97-99}$ computer-aided drug design, ${ }^{100-103}$ and fragment-based drug design (FBDD). ${ }^{104-107}$ In addition, extensive efforts from medicinal and organic chemists will provide efficient synthetic approaches for creating novel compound libraries of spirooxindole analogues necessary for significant SAR explorations toward antiviral drug discovery.

\section{Acknowledgments}

This work was supported by Grants P30 DA028821, R01 DA038446, and R01 AI111464 from the National Institutes of Health, the R. A. Welch Foundation Chemistry, a Biology Collaborative Grant from Gulf Coast Consortia (GCC) for Chemical Genomics, a training fellowship from the Center for Addiction Research (NIDA Grant T32 DA07287), and the John Sealy Memorial Endowment Fund at UTMB.

\section{ABBREVIATIONS}

\begin{tabular}{|c|c|}
\hline HIV & human immunodeficiency virus \\
\hline HSV & herpes simplex virus \\
\hline VZV & varicella-zoster virus \\
\hline HCMV & human cytomegalovirus \\
\hline HBV & hepatitis B virus \\
\hline $\mathrm{HCV}$ & hepatitis $\mathrm{C}$ virus \\
\hline MAP & mitogen activated protein \\
\hline SI & selection index \\
\hline AIDS & acquired immunodeficiency syndrome \\
\hline HAART & highly active antiretroviral therapy \\
\hline NNRTI & non-nucleoside reverse transcriptase inhibitors \\
\hline Vpr & viral protein $R$ \\
\hline RSV & respiratory syncytial virus \\
\hline DENV & dengue virus \\
\hline NS4B & nonstructural protein $4 \mathrm{~B}$ \\
\hline NS5A & nonstructural protein $5 \mathrm{~A}$ \\
\hline NBS & $N$-bromosuccinimide \\
\hline THF & tetrahydrofuran \\
\hline
\end{tabular}




$$
\begin{array}{ll}
\text { IC }_{\mathbf{5 0}} & \text { concentration causing } 50 \% \text { inhibition of antiviral activity } \\
\mathbf{T C}_{\mathbf{5 0}} & 50 \% \text { toxic concentration } \\
\mathbf{C C}_{\mathbf{5 0}} & 50 \% \text { cytotoxicity concentration } \mathrm{SI}=\mathrm{TC}_{50} / \mathrm{IC}_{50}
\end{array}
$$

\section{References}

1. Menendez-Arias L, Gago F. Antiviral agents: structural basis of action and rational design. Subcell Biochem. 2013; 68:599-630. [PubMed: 23737066]

2. De Clercq E. Highlights in antiviral drug research: antivirals at the horizon. Med Res Rev. 2013; 33:1215-1248. [PubMed: 22553111]

3. Antiretroviral drugs used in the treatment of HIV infection. http://www.fda.gov/ForPatients/Illness/ HIVAIDS/Treatment/ucm118915.htm

4. De Clercq E. Antivirals and antiviral strategies. Nat Rev Microbiol. 2004; 2:704-720. [PubMed: 15372081]

5. Wainberg MA. Perspectives on antiviral drug development. Antiviral Res. 2009; 81:1-5. [PubMed: 18948140]

6. De Clercq E. A cutting-edge view on the current state of antiviral drug development. Med Res Rev. 2013; 33:1249-1277. [PubMed: 23495004]

7. Lim SP, Wang QY, Noble CG, Chen YL, Dong H, Zou B, Yokokawa F, Nilar S, Smith P, Beer D, Lescar J, Shi PY. Ten years of dengue drug discovery: progress and prospects. Antiviral Res. 2013; 100:500-519. [PubMed: 24076358]

8. Zheng Y, Tice CM, Singh SB. The use of spirocyclic scaffolds in drug discovery. Bioorg Med Chem Lett. 2014; 24:3673-3682. [PubMed: 25052427]

9. Galliford CV, Scheidt KA. Pyrrolidinyl-spirooxindole natural products as inspirations for the development of potential therapeutic agents. Angew Chem, Int Ed. 2007; 46:8748-8758.

10. Yu B, Yu DQ, Liu HM. Spirooxindoles: promising scaffolds for anticancer agents. Eur J Med Chem. 2015; 97:673-698. [PubMed: 24994707]

11. Veber DF, Johnson SR, Cheng HY, Smith BR, Ward KW, Kopple KD. Molecular properties that influence the oral bioavailability of drug candidates. J Med Chem. 2002; 45:2615-2623. [PubMed: 12036371]

12. Lovering F. Escape from flatland 2: complexity and promiscuity. MedChemComm. 2013; 4:515519.

13. Rios R. Enantioselective methodologies for the synthesis of spiro compounds. Chem Soc Rev. 2012; 41:1060-1074. [PubMed: 21975423]

14. Ball-Jones NR, Badillo JJ, Franz AK. Strategies for the enantioselective synthesis of spirooxindoles. Org Biomol Chem. 2012; 10:5165-5181. [PubMed: 22581310]

15. Hong L, Wang R. Recent advances in asymmetric organocatalytic construction of 3,3' -spirocyclic oxindoles. Adv Synth Catal. 2013; 355:1023-1052.

16. Senger MR, Fraga CA, Dantas RF, Silva FR. Filtering promiscuous compounds in early drug discovery: is it a good idea? Drug Discovery Today. 2016; Epub ahead of print. doi: 10.1016/ j.drudis.2016.02.004

17. Pouliot M, Jeanmart S. Pan assay interference compounds (PAINS) and other promiscuous compounds in antifungal research. J Med Chem. 2016; 59:497-503. [PubMed: 26313340]

18. Whitty A. Growing PAINS in academic drug discovery. Future Med Chem. 2011; 3:797-801. [PubMed: 21644825]

19. Baell JB, Holloway GA. New substructure filters for removal of pan assay interference compounds (PAINS) from screening libraries and for their exclusion in bioassays. J Med Chem. 2010; 53:2719-2740. [PubMed: 20131845]

20. Ding K, Lu Y, Nikolovska-Coleska Z, Qiu S, Ding Y, Gao W, Stuckey J, Krajewski K, Roller PP, Tomita Y, Parrish DA, Deschamps JR, Wang S. Structure-based design of potent non-peptide MDM2 inhibitors. J Am Chem Soc. 2005; 127:10130-10131. [PubMed: 16028899] 
21. Zhao Y, Yu S, Sun W, Liu L, Lu J, McEachern D, Shargary S, Bernard D, Li X, Zhao T, Zou P, Sun D, Wang S. A potent small-molecule inhibitor of the MDM2-p53 interaction (MI-888) achieved complete and durable tumor regression in mice. J Med Chem. 2013; 56:5553-5561. [PubMed: 23786219]

22. Soupart A, Gross P, Legros JJ, Alfoldi S, Annane D, Heshmati HM, Decaux G. Successful longterm treatment of hyponatremia in syndrome of inappropriate antidiuretic hormone secretion with satavaptan (SR121463B), an orally active nonpeptide vasopressin V2-receptor antagonist. Clin J Am Soc Nephrol. 2006; 1:1154-1160. [PubMed: 17699341]

23. Gines P, Wong F, Watson H, Milutinovic S, del Arbol LR, Olteanu D, Hypo CATSI. Effects of satavaptan, a selective vasopressin $\mathrm{V}(2)$ receptor antagonist, on ascites and serum sodium in cirrhosis with hyponatremia: a randomized trial. Hepatology. 2008; 48:204-213. [PubMed: 18508290]

24. Rottmann M, McNamara C, Yeung BK, Lee MC, Zou B, Russell B, Seitz P, Plouffe DM, Dharia NV, Tan J, Cohen SB, Spencer KR, Gonzalez-Paez GE, Lakshminarayana SB, Goh A, Suwanarusk R, Jegla T, Schmitt EK, Beck HP, Brun R, Nosten F, Renia L, Dartois V, Keller TH, Fidock DA, Winzeler EA, Diagana TT. Spiroindolones, a potent compound class for the treatment of malaria. Science. 2010; 329:1175-1180. [PubMed: 20813948]

25. Pilatova M, Sarissky M, Kutschy P, Mirossay A, Mezencev R, Curillova Z, Suchy M, Monde K, Mirossay L, Mojzis J. Cruciferous phytoalexins: antiproliferative effects in T-Jurkat leukemic cells. Leuk Res. 2005; 29:415-421. [PubMed: 15725476]

26. Hostetler G, Dunn D, McKenna BA, Kopec K, Chatterjee S. 1-Thia-4,7-diazaspiro[4.4]nonane-3,6-dione: a structural motif for 5-hydroxytryptamine 6 receptor antagonism. Chem Biol Drug Des. 2014; 83:149-153. [PubMed: 24119217]

27. Stratmann K, Moore RE, Bonjouklian R, Deeter JB, Patterson GML, Shaffer S, Smith CD, Smitka TA. Welwitindolinones, unusual alkaloids from the Blue-Green algae Hapalosiphon welwitschii and Westiella intricata. relationship to fischerindoles and hapalinodoles. J Am Chem Soc. 1994; 116:9935-9942.

28. Eastwood P, Gonzalez J, Gomez E, Vidal B, Caturla F, Roca R, Balague C, Orellana A, Dominguez M. Indolin-2-one p38alpha inhibitors I: design, profiling and crystallographic binding mode. Bioorg Med Chem Lett. 2011; 21:4130-4133. [PubMed: 21696951]

29. Stevens FC, Bloomquist WE, Borel AG, Cohen ML, Droste CA, Heiman ML, Kriauciunas A, Sall DJ, Tinsley FC, Jesudason CD. Potent oxindole based human beta3 adrenergic receptor agonists. Bioorg Med Chem Lett. 2007; 17:6270-6273. [PubMed: 17911024]

30. HIV/AIDS Global Health Observatory (GHO) data. http://www.who.int/gho/hiv/en/ (accessed Dec 10, 2015)

31. Achenbach CJ, Scarsi KK, Murphy RL. Abacavir/Lamivudine fixed-dose combination antiretroviral therapy for the treatment of HIV. Adv Ther. 2010; 27:1-16. [PubMed: 20204580]

32. Crutchley RD, Guduru RC, Cheng AM. Evaluating the role of atazanavir/cobicistat and darunavir/ cobicistat fixed-dose combinations for the treatment of HIV-1 infection. HIV/AIDS. 2016; 8:4765. [PubMed: 27022304]

33. Permpalung N, Putcharoen O, Avihingsanon A, Ruxrungtham K. Treatment of HIV infection with once-daily regimens. Expert Opin Pharmacother. 2012; 13:2301-2317. [PubMed: 23043453]

34. Flexner C. HIV-protease inhibitors. N Engl J Med. 1998; 338:1281-1292. [PubMed: 9562584]

35. De Clercq E. New developments in anti-HIV chemotherapy. Biochim Biophys Acta, Mol Basis Dis. 2002; 1587:258-275.

36. Tamalet C, Pasquier C, Yahi N, Colson P, Poizot-Martin I, Lepeu G, Gallais H, Massip P, Puel J, Izopet J. Prevalence of drug resistant mutants and virological response to combination therapy in patients with primary HIV-1 infection. J Med Virol. 2000; 61:181-186. [PubMed: 10797372]

37. Ghosh AK, Schiltz G, Perali RS, Leshchenko S, Kay S, Walters DE, Koh Y, Maeda K, Mitsuya H. Design and synthesis of novel HIV-1 protease inhibitors incorporating oxyindoles as the $\mathrm{P}^{\prime}{ }_{2}$ ligands. Bioorg Med Chem Lett. 2006; 16:1869-1873. [PubMed: 16480871]

38. Ghosh AK, Swanson LM, Cho H, Leshchenko S, Hussain KA, Kay S, Walters DE, Koh Y, Mitsuya H. Structure-based design: synthesis and biological evaluation of a series of novel cycloamidederived HIV-1 protease inhibitors. J Med Chem. 2005; 48:3576-3585. [PubMed: 15887965] 
39. Reid RC, Pattenden LK, Tyndall JD, Martin JL, Walsh T, Fairlie DP. Countering cooperative effects in protease inhibitors using constrained beta-strand-mimicking templates in focused combinatorial libraries. J Med Chem. 2004; 47:1641-1651. [PubMed: 15027855]

40. Glenn MP, Pattenden LK, Reid RC, Tyssen DP, Tyndall JD, Birch CJ, Fairlie DP. Beta-strand mimicking macrocyclic amino acids: templates for protease inhibitors with antiviral activity. $\mathrm{J}$ Med Chem. 2002; 45:371-381. [PubMed: 11784141]

41. Jiang T, Kuhen KL, Wolff K, Yin H, Bieza K, Caldwell J, Bursulaya B, Wu TY, He Y. Design, synthesis and biological evaluations of novel oxindoles as HIV-1 non-nucleoside reverse transcriptase inhibitors. Part I. Bioorg Med Chem Lett. 2006; 16:2105-2108. [PubMed: 16480865]

42. Jiang T, Kuhen KL, Wolff K, Yin H, Bieza K, Caldwell J, Bursulaya B, Tuntland T, Zhang K, Karanewsky D, He Y. Design, synthesis, and biological evaluations of novel oxindoles as HIV-1 non-nucleoside reverse transcriptase inhibitors. Part 2. Bioorg Med Chem Lett. 2006; 16:21092112. [PubMed: 16464578]

43. Aida Y, Matsuda G. Role of Vpr in HIV-1 nuclear import: therapeutic implications. Curr HIV Res. 2009; 7:136-143. [PubMed: 19275582]

44. Nishizawa M, Kamata M, Katsumata R, Aida Y. A carboxy-terminally truncated form of the human immunodeficiency virus type $1 \mathrm{Vpr}$ protein induces apoptosis via $\mathrm{G}(1)$ cell cycle arrest. J Virol. 2000; 74:6058-6067. [PubMed: 10846089]

45. Schrofelbauer B, Hakata Y, Landau NR. HIV-1 Vpr function is mediated by interaction with the damage-specific DNA-binding protein DDB1. Proc Natl Acad Sci USA. 2007; 104:4130-4135. [PubMed: 17360488]

46. Hashizume C, Kuramitsu M, Zhang X, Kurosawa T, Kamata M, Aida Y. Human immunodeficiency virus type $1 \mathrm{Vpr}$ interacts with spliceosomal protein SAP145 to mediate cellular pre-mRNA splicing inhibition. Microbes Infect. 2007; 9:490-497. [PubMed: 17347016]

47. Hagiwara K, Murakami T, Xue G, Shimizu Y, Takeda E, Hashimoto Y, Honda K, Kondoh Y, Osada $\mathrm{H}$, Tsunetsugu-Yokota Y, Aida Y. Identification of a novel Vpr-binding compound that inhibits HIV-1 multiplication in macrophages by chemical array. Biochem Biophys Res Commun. 2010; 403:40-45. [PubMed: 21036153]

48. Oertel MD. RespiGam: an RSV immune globulin. Pediatr Nurs. 1996; 22:525-528. [PubMed: 9087091]

49. The IMpact-RSV Study Group. Palivizumab, a humanized respiratory syncytial virus monoclonal antibody, reduces hospitalization from respiratory syncytial virus infection in high-risk infants. Pediatrics. 1998; 102:531-537.

50. Feltes TF, Sondheimer HM, Tulloh RM, Harris BS, Jensen KM, Losonsky GA, Griffin MP, Motavizumab Cardiac Study, G. A randomized controlled trial of motavizumab versus palivizumab for the prophylaxis of serious respiratory syncytial virus disease in children with hemodynamically significant congenital heart disease. Pediatr Res. 2011; 70:186-191. [PubMed: 21522037]

51. Anderson LJ, Dormitzer PR, Nokes DJ, Rappuoli R, Roca A, Graham BS. Strategic priorities for respiratory syncytial virus (RSV) vaccine development. Vaccine. 2013; 31(Suppl. 2):B209-B215. [PubMed: 23598484]

52. DeVincenzo J, Lambkin-Williams R, Wilkinson T, Cehelsky J, Nochur S, Walsh E, Meyers R, Gollob J, Vaishnaw A. A randomized, double-blind, placebo-controlled study of an RNAi-based therapy directed against respiratory syncytial virus. Proc Natl Acad Sci USA. 2010; 107:8800 8805. [PubMed: 20421463]

53. Henderson EA, Alber DG, Baxter RC, Bithell SK, Budworth J, Carter MC, Chubb A, Cockerill GS, Dowdell VC, Fraser IJ, Harris RA, Keegan SJ, Kelsey RD, Lumley JA, Stables JN, Weerasekera N, Wilson LJ, Powell KL. 1,4-benzodiazepines as inhibitors of respiratory syncytial virus. The identification of a clinical candidate. J Med Chem. 2007; 50:1685-1692. [PubMed: 17341059]

54. Sperandio, D., Mackman, R. Respiratory Syncytial Virus Fusion Inhibitors. In: Desai, MC., Meanwell, NA., editors. Successful Strategies for the Discovery of Antiviral Drugs. Royal Society of Chemistry; Oxford, UK: 2013. p. 29-62. 
55. Combrink KD, Gulgeze HB, Thuring JW, Yu KL, Civiello RL, Zhang Y, Pearce BC, Yin Z, Langley DR, Kadow KF, Cianci CW, Li Z, Clarke J, Genovesi EV, Medina I, Lamb L, Yang Z, Zadjura L, Krystal M, Meanwell NA. Respiratory syncytial virus fusion inhibitors Part 6: an examination of the effect of structural variation of the benzimidazol-2-one heterocycle moiety. Bioorg Med Chem Lett. 2007; 17:4784-4790. [PubMed: 17616396]

56. Cianci C, Langley DR, Dischino DD, Sun Y, Yu KL, Stanley A, Roach J, Li Z, Dalterio R, Colonno R, Meanwell NA, Krystal M. Targeting a binding pocket within the trimer-of-hairpins: small-molecule inhibition of viral fusion. Proc Natl Acad Sci USA. 2004; 101:15046-15051. [PubMed: 15469910]

57. Battles MB, Langedijk JP, Furmanova-Hollenstein P, Chaiwatpongsakorn S, Costello HM, Kwanten L, Vranckx L, Vink P, Jaensch S, Jonckers TH, Koul A, Arnoult E, Peeples ME, Roymans D, McLellan JS. Molecular mechanism of respiratory syncytial virus fusion inhibitors. Nat Chem Biol. 2016; 12:87-93. [PubMed: 26641933]

58. Cockerill, S., Pilkington, C., Lumley, J., Angell, R., Mathews, N. Pharmaceutical compounds. WO 2013/068769 A1. 2013.

59. He, H., Shi, W., Jiang, Z., Han, L., Sun, J., Li, J., Chen, S. Imidazole derivatives used as antiviral agent and use thereof in preparation of medicament. WO 2015/085844 A1. 2015.

60. Feng, S., Gao, L., Guo, L., Huang, M., Liang, C., Wang, B., Wang, L., Wu, G., Yun, H., Zhang, W., Zheng, X., Zhu, W. Aza-oxo-indoles for the treatment and prophylaxis of respiratory syncytial virus infection. WO 2014/184163 A1. 2014.

61. Wang, L., Yun, H., Zhang, W., Zheng, X. Novel azaoxo-indoles for the treatment and prophylaxis of respiratory syncytial virus infection. WO 2015/022301 A1. 2014.

62. Tahri, A., Vendeville, SMH., Jonckers, THM., Raboisson, P., J-M, B., Hu, L., Demin, SD., Cooymans, LP. RSV antiviral compounds. WO 2014/060411 A1. 2014.

63. WHO. Dengue severe dengue fact sheet 117. http://www.who.int/mediacentre/factsheets/fs117/en/ (accessed Dec 17, 2015)

64. WHO. Impact of Dengue. http://www.who.int/csr/disease/dengue/impact/en/

65. Fink K, Shi PY. Live attenuated vaccine: the first clinically approved dengue vaccine? Expert Rev Vaccines. 2014; 13:185-188. [PubMed: 24350687]

66. Dengvaxia ${ }^{\circledR}$, world's first dengue vaccine, approved in Mexico. http://www.sanofipasteur.com/en/ articles/dengvaxia-world-s-first-dengue-vaccine-approved-in-mexico.aspx (accessed Dec 9, 2015)

67. Nguyen NM, Tran CN, Phung LK, Duong KT, Huynh Hle A, Farrar J, Nguyen QT, Tran HT, Nguyen CV, Merson L, Hoang LT, Hibberd ML, Aw PP, Wilm A, Nagarajan N, Nguyen DT, Pham MP, Nguyen TT, Javanbakht H, Klumpp K, Hammond J, Petric R, Wolbers M, Nguyen CT, Simmons CP. A randomized, double-blind placebo controlled trial of balapiravir, a polymerase inhibitor, in adult dengue patients. J Infect Dis. 2013; 207:1442-1450. [PubMed: 22807519]

68. Low JG, Sung C, Wijaya L, Wei Y, Rathore AP, Watanabe S, Tan BH, Toh L, Chua LT, Hou Y, Chow A, Howe S, Chan WK, Tan KH, Chung JS, Cherng BP, Lye DC, Tambayah PA, Ng LC, Connolly J, Hibberd ML, Leo YS, Cheung YB, Ooi EE, Vasudevan SG. Efficacy and safety of celgosivir in patients with dengue fever (CELADEN): a phase $1 \mathrm{~b}$, randomised, double-blind, placebo-controlled, proof-of-concept trial. Lancet Infect Dis. 2014; 14:706-715. [PubMed: 24877997]

69. Tricou V, Minh NN, Van TP, Lee SJ, Farrar J, Wills B, Tran HT, Simmons CP. A randomized controlled trial of chloroquine for the treatment of dengue in Vietnamese adults. PLoS Neglected Trop Dis. 2010; 4:e785.

70. Tam DT, Ngoc TV, Tien NT, Kieu NT, Thuy TT, Thanh LT, Tam CT, Truong NT, Dung NT, Qui PT, Hien TT, Farrar JJ, Simmons CP, Wolbers M, Wills BA. Effects of short-course oral corticosteroid therapy in early dengue infection in Vietnamese patients: a randomized, placebocontrolled trial. Clin Infect Dis. 2012; 55:1216-1224. [PubMed: 22865871]

71. Whitehorn J, Nguyen CV, Khanh LP, Kien DT, Quyen NT, Tran NT, Hang NT, Truong NT, Hue Tai LT, Cam Huong NT, Nhon VT, Van Tram T, Farrar J, Wolbers M, Simmons CP, Wills B. Lovastatin for the treatment of adult patients with dengue: a randomized, double-blind, placebocontrolled trial. Clin Infect Dis. 2016; 62:468-476. [PubMed: 26565005] 
72. Wang QY, Dong H, Zou B, Karuna R, Wan KF, Zou J, Susila A, Yip A, Shan C, Yeo KL, Xu H, Ding M, Chan WL, Gu F, Seah PG, Liu W, Lakshminarayana SB, Kang C, Lescar J, Blasco F, Smith PW, Shi PY. Discovery of dengue virus NS4B inhibitors. J Virol. 2015; 89:8233-8244. [PubMed: 26018165]

73. Zou B, Chan WL, Ding M, Leong SY, Nilar S, Seah PG, Liu W, Karuna R, Blasco F, Yip A, Chao A, Susila A, Dong H, Wang QY, Xu HY, Chan K, Wan KF, Gu F, Diagana TT, Wagner T, Dix I, Shi PY, Smith PW. Lead optimization of spiropyrazolopyridones: a new and potent class of dengue virus inhibitors. ACS Med Chem Lett. 2015; 6:344-348. [PubMed: 25878766]

74. Chan, WL., Ding, M., Zou, B. Spiropyrazolopyridine derivatives and uses thereof for the treatment of viral infections. WO 2014/167528 A1. 2014.

75. Green S, Rothman A. Immunopathological mechanisms in dengue and dengue hemorrhagic fever. Curr Opin Infect Dis. 2006; 19:429-436. [PubMed: 16940865]

76. Chen M, Lin S, Li L, Zhu C, Wang X, Wang Y, Jiang B, Wang S, Li Y, Jiang J, Shi J. Enantiomers of an indole alkaloid containing unusual dihydrothiopyran and 1,2,4-thiadiazole rings from the root of Isatis indigotica. Org Lett. 2012; 14:5668-5671. [PubMed: 23131196]

77. He WY, Gao RM, Li XQ, Jiang JD, Li YH. In vitro anti-influenza virus activity of 10 traditional Chinese medicines. Acta Pharm Sinica. 2010; 45:395-398.

78. Candeias MF, Abreu P, Pereira A, Cruz-Morais J. Effects of strictosamide on mouse brain and kidney $\mathrm{Na}^{+}, \mathrm{K}^{+}$-ATPase and $\mathrm{Mg}^{2+}$-ATPase activities. J Ethnopharmacol. 2009; 121:117-122. [PubMed: 18992802]

79. Li Z, Li Z, Lin Y, Meng Z, Ding G, Cao L, Li N, Liu W, Xiao W, Wu X, Xu J. Synthesis and biological evaluation of strictosamide derivatives with improved antiviral and antiproliferative activities. Chem Biol Drug Des. 2015; 86:523-530. [PubMed: 25589048]

80. Kurbatov SV, Zarubaev VV, Karpinskaya LA, Shvets AA, Kletsky ME, Burov ON, Morozov PG, Kiselev OI, Minkin VI. Synthesis and antiviral activity of bis-spirocyclic derivatives of rhodanine. Russ Chem Bull. 2014; 63:1130-1136.

81. Brummelkamp, TR., Carette, JE. 16 as a target for antiviral compounds WO 2011/160043 A3. 2011. p. LA2G

82. Burckstummer, T., Salic, S., Fischl, W., Kubicek, S. Antiviral Compounds. Patent WO 2015/018797A3. 2015.

83. Vandyck, K., Hache, GYP., Rombouts, G., Verschueren, WG., Raboisson, P., J-M, B. 4,4Disubstituted-1,4-dihydropyrimidines and the use thereof as medicaments for the treatment of hepatitis B. WO 2013/102655 A1. 2013.

84. Belda O, Targett-Adams P. Small molecule inhibitors of the hepatitis C virus-encoded NS5A protein. Virus Res. 2012; 170:1-14. [PubMed: 23009750]

85. Appel N, Schaller T, Penin F, Bartenschlager R. From structure to function: new insights into hepatitis C virus RNA replication. J Biol Chem. 2006; 281:9833-9836. [PubMed: 16407182]

86. Cordek DG, Bechtel JT, Maynard AT, Kazmierski WM, Cameron CE. Targeting the Ns5a protein of Hcv: an emerging option. Drugs Future. 2011; 36:691-711. [PubMed: 23378700]

87. Belema M, Nguyen VN, Bachand C, Deon DH, Goodrich JT, James CA, Lavoie R, Lopez OD, Martel A, Romine JL, Ruediger EH, Snyder LB, Laurent DR, St Yang F, Zhu J, Wong HS, Langley DR, Adams SP, Cantor GH, Chimalakonda A, Fura A, Johnson BM, Knipe JO, Parker DD, Santone KS, Fridell RA, Lemm JA, O’Boyle DR 2nd, Colonno RJ, Gao M, Meanwell NA, Hamann LG. Hepatitis C virus NS5A replication complex inhibitors: the discovery of daclatasvir. J Med Chem. 2014; 57:2013-2032. [PubMed: 24521299]

88. Link JO, Taylor JG, Xu L, Mitchell M, Guo H, Liu H, Kato D, Kirschberg T, Sun J, Squires N, Parrish J, Keller T, Yang ZY, Yang C, Matles M, Wang Y, Wang K, Cheng G, Tian Y, Mogalian E, Mondou E, Cornpropst M, Perry J, Desai MC. Discovery of ledipasvir (GS-5885): a potent, oncedaily oral NS5A inhibitor for the treatment of hepatitis C virus infection. J Med Chem. 2014; 57:2033-2046. [PubMed: 24320933]

89. Belema M, Meanwell NA. Discovery of daclatasvir, a pan-genotypic hepatitis C virus NS5A replication complex inhibitor with potent clinical effect. J Med Chem. 2014; 57:5057-5071. [PubMed: 24749835] 
90. Liang TJ, Ghany MG. Current and future therapies for hepatitis C virus infection. N Engl J Med. 2013; 368:1907-1917. [PubMed: 23675659]

91. Dabbouseh NM, Jensen DM. Future therapies for chronic hepatitis C. Nat Rev Gastroenterol Hepatol. 2013; 10:268-276. [PubMed: 23419289]

92. Pawlotsky JM. NS5A inhibitors in the treatment of hepatitis C. J Hepatol. 2013; 59:375-382. [PubMed: 23567084]

93. Suk-Fong Lok A. HCV NS5A inhibitors in development. Clin Liver Dis. 2013; 17:111-121. [PubMed: 23177287]

94. Belema M, Lopez OD, Bender JA, Romine JL, St Laurent DR, Langley DR, Lemm JA, O’Boyle DR 2nd, Sun JH, Wang C, Fridell RA, Meanwell NA. Discovery and development of hepatitis C virus NS5A replication complex inhibitors. J Med Chem. 2014; 57:1643-1672. [PubMed: 24621191]

95. Zhang, Y., Zhang, J., Xie, H., Yu, T., Luo, H., Ren, Q., Wu, X., Fu, C., Li, S., Lei, Y., Hu, P. Pyrrolidine derivative used as hepatitis $\mathrm{c}$ inhibitor and application thereof in medicine. $\mathrm{CN}$ 103420991. 2013.

96. Ding C, Zhang Y, Chen H, Yang Z, Wild C, Ye N, Ester CD, Xiong A, White MA, Shen Q, Zhou J. Oridonin ring A-based diverse constructions of enone functionality: identification of novel dienone analogues effective for highly aggressive breast cancer by inducing apoptosis. J Med Chem. 2013; 56:8814-8825. [PubMed: 24128046]

97. Ye N, Chen CH, Chen T, Song Z, He JX, Huan XJ, Song SS, Liu Q, Chen Y, Ding J, Xu Y, Miao $\mathrm{ZH}$, Zhang A. Design, synthesis, and biological evaluation of a series of benzo[de] $[1,7]$ naphthyridin-7 $(8 H)$-ones bearing a functionalized longer chain appendage as novel PARP1 inhibitors. J Med Chem. 2013; 56:2885-2903. [PubMed: 23473053]

98. Ye N, Wu Q, Zhu L, Zheng L, Gao B, Zhen X, Zhang A. Further SAR study on 11-O-substituted aporphine analogues: identification of highly potent dopamine D3 receptor ligands. Bioorg Med Chem. 2011; 19:1999-2008. [PubMed: 21334902]

99. Kalyaanamoorthy S, Chen YP. Structure-based drug design to augment hit discovery. Drug Discovery Today. 2011; 16:831-839. [PubMed: 21810482]

100. Chen H, Wang CZ, Ding C, Wild C, Copits B, Swanson GT, Johnson KM, Zhou J. A combined bioinformatics and chemoinformatics approach for developing asymmetric bivalent AMPA receptor positive allosteric modulators as neuroprotective agents. ChemMedChem. 2013; 8:226230. [PubMed: 23281122]

101. Reker D, Schneider G. Active-learning strategies in computer-assisted drug discovery. Drug Discovery Today. 2015; 20:458-465. [PubMed: 25499665]

102. Ye N, Zhu Y, Chen H, Liu Z, Mei FC, Wild C, Chen H, Cheng X, Zhou J. Structure-activity relationship studies of substituted 2-(isoxazol-3-yl)-2-oxo- $N^{\prime}$-phenyl-acetohydrazonoyl cyanide analogues: identification of potent exchange proteins directly activated by cAMP (EPAC) antagonists. J Med Chem. 2015; 58:6033-6047. [PubMed: 26151319]

103. Chen H, Tsalkova T, Chepurny OG, Mei FC, Holz GG, Cheng X, Zhou J. Identification and characterization of small molecules as potent and specific EPAC2 antagonists. J Med Chem. 2013; 56:952-962. [PubMed: 23286832]

104. Chen H, Zhou X, Wang A, Zheng Y, Gao Y, Zhou J. Evolutions in fragment-based drug design: the deconstruction-reconstruction approach. Drug Discovery Today. 2015; 20:105-113. [PubMed: 25263697]

105. Chen H, Yang Z, Ding C, Chu L, Zhang Y, Terry K, Liu H, Shen Q, Zhou J. Fragment-based drug design and identification of HJC0123, a novel orally bioavailable STAT3 inhibitor for cancer therapy. Eur J Med Chem. 2013; 62:498-507. [PubMed: 23416191]

106. Hajduk PJ, Greer J. A decade of fragment-based drug design: strategic advances and lessons learned. Nat Rev Drug Discovery. 2007; 6:211-219. [PubMed: 17290284]

107. Baker M. Fragment-based lead discovery grows up. Nat Rev Drug Discovery. 2013; 12:5-7. [PubMed: 23274457] 


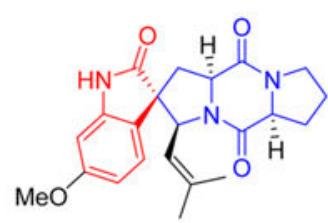

Spirotryprostatin A (1)

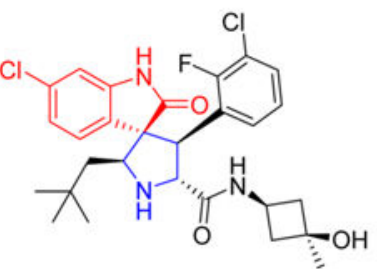

Ml-888 (5) p53/MDM2 antagonist

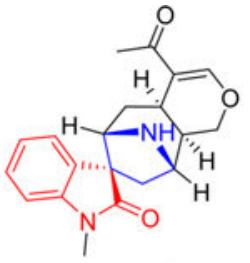

Alstonisine (2)

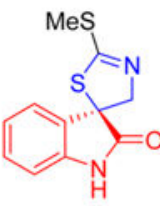

Spirobrassinin (3)

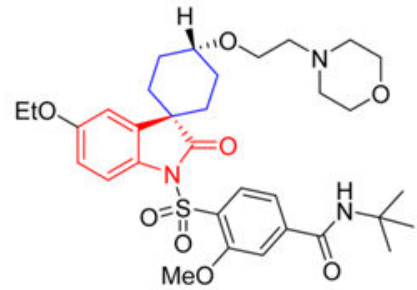

Satavaptan (6) Vasopressin-2 receptor antagonist

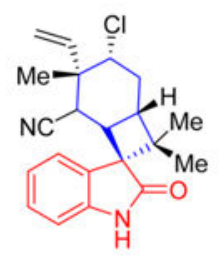

(+)-Welwitindolinone A (4)

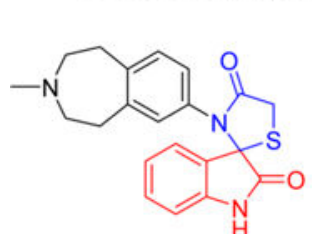

8 $5-\mathrm{HT}_{6}$ antagonist<smiles>Cc1ccc(C(=O)NC2CC2)cc1-c1ccc2c(c1)NC(=O)C21CCC1</smiles>

9

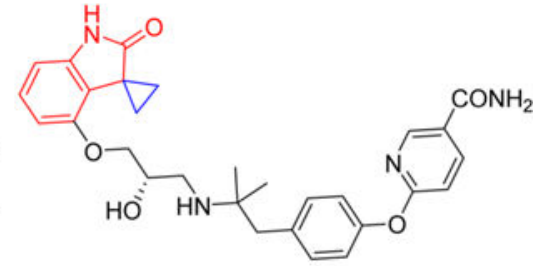

10

$\beta_{3}$ adrenergic receptor agonist

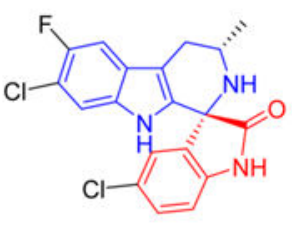

NITD 609 (7) Antimalarial agent

Figure 1.

Selected examples of natural products and pharmaceutical drugs or lead compounds with spirooxindole scaffold, which is depicted with red and blue representing two key moieties. 


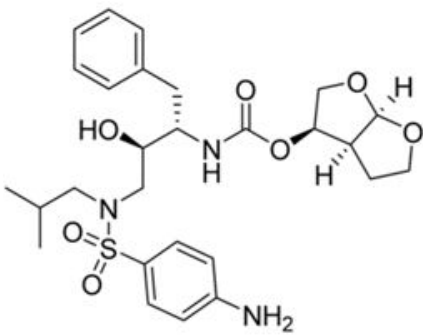

Darunavir (11): $K_{\mathrm{i}}=15 \pm 1 \mathrm{pM}$

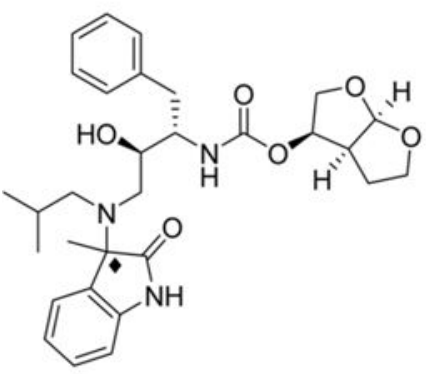

12a (isomer $\mathrm{A}$ ): $K_{\mathrm{i}}=6 \pm 0.6 \mathrm{nM}$ $12 \mathrm{~b}$ (isomer $\mathrm{B}$ ): $K_{\mathrm{i}}=3 \pm 0.3 \mathrm{nM}$
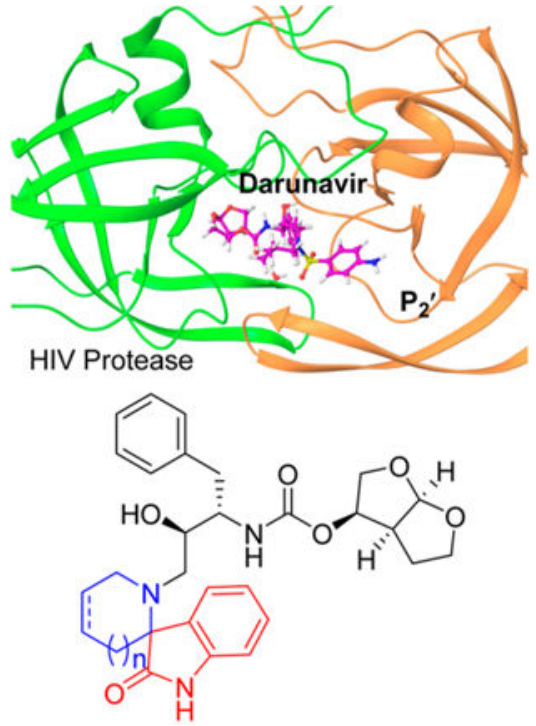

13 (single bond, $\mathrm{n}=1$ ): $K_{\mathrm{i}}=126 \pm 0.5 \mathrm{nM}$

14 (double bond, $\mathrm{n}=1$ ): $K_{\mathrm{i}}>1000 \mathrm{nM}$

15 (single bond, $\mathrm{n}=2$ ): $K_{\mathrm{i}}>1000 \mathrm{nM}$

16 (double bond, $\mathrm{n}=2$ ): $K_{\mathrm{i}}>1000 \mathrm{nM}$

Figure 2.

Selected examples of HIV protease inhibitors with spirooxindole scaffold and the cocrystal structure of $\mathbf{1 1}$ and HIV protease (PDB code 2IEN). 


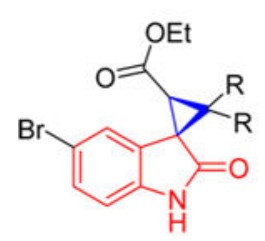

17: $\mathrm{R}=\mathrm{H}$

18: $R=M e$

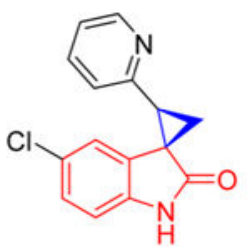

19

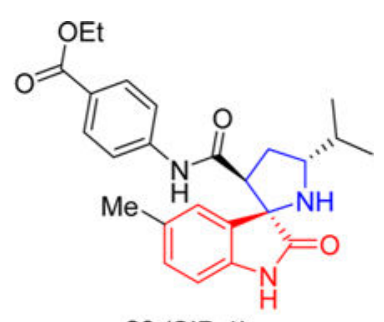

$20(\mathrm{SIP}-1)$

Figure 3.

Selected examples of HIV non-nucleoside reverse transcriptase inhibitors with spirooxindole scaffold. 


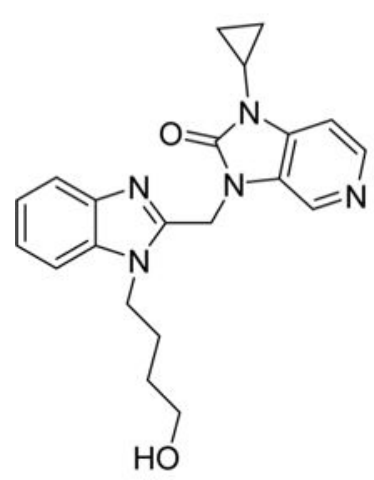

21 (BMS433771)

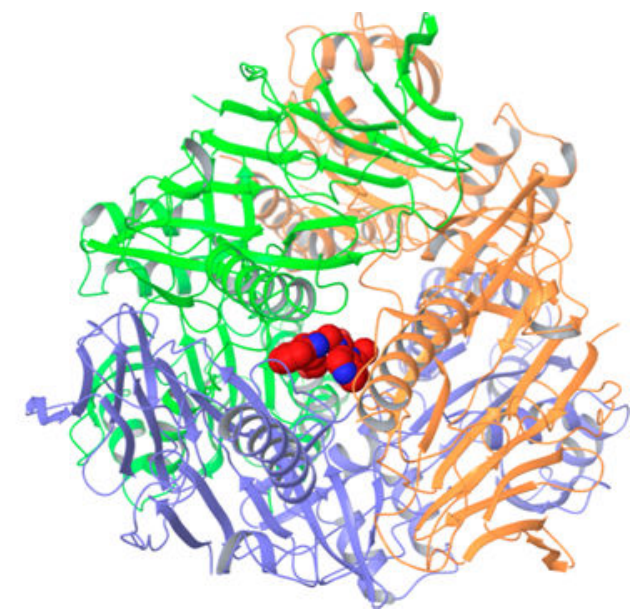

Figure 4.

Structure of BMS433771 (21) and the cocrystal structure of 21 and 3-fold-symmetric cavity in prefusion RSV fusion protein (PDB code 5EA7). 


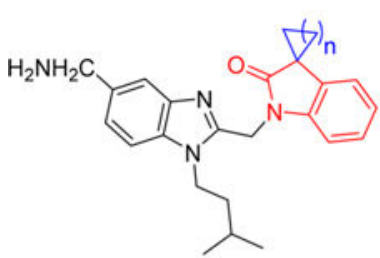

22: $\mathrm{n}=1$

23: $n=2$

24: $n=3$

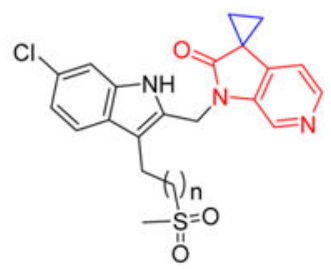

$34 \mathrm{n}=1 \mathrm{EC}_{50}=0.005 \mu \mathrm{M}$

$35 \mathrm{n}=2 \mathrm{EC}_{50}=0.006 \mu \mathrm{M}$

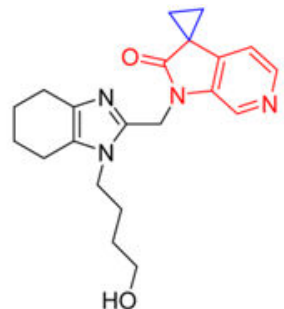

25

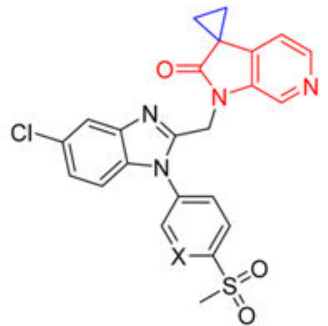

$36 \mathrm{X}=\mathrm{N} \quad \mathrm{EC}_{50}=0.004 \mu \mathrm{M}$

$37 \mathrm{X}=\mathrm{C} \quad \mathrm{EC}_{50}=0.025 \mu \mathrm{M}$

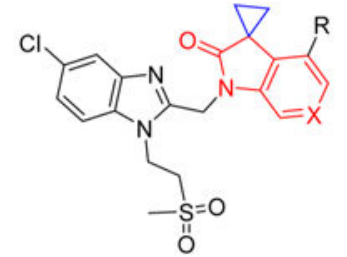

$26 \mathrm{X}=\mathrm{C}, \mathrm{R}=\mathrm{F} \quad \mathrm{EC}_{50}=0.020 \mu \mathrm{M}$ $27 \mathrm{X}=\mathrm{C}, \mathrm{R}=\mathrm{Cl} \mathrm{EC}_{50}=0.066 \mu \mathrm{M}$ $28 X=C, R=B r E C_{50}=0.205 \mu \mathrm{M}$ $29 \mathrm{X}=\mathrm{N}, \mathrm{R}=\mathrm{H} \quad \mathrm{EC}_{50}=0.012 \mu \mathrm{M}$

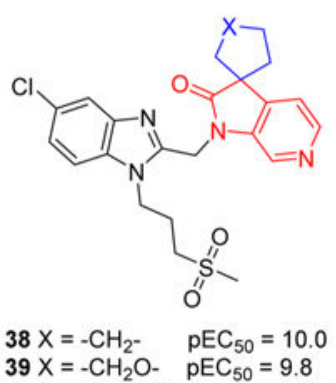

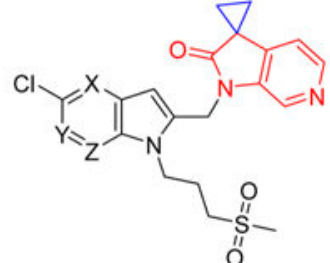

$30 X=Y=Z=C \quad E_{50}=0.003 \mu M$ $31 \mathrm{Y}=\mathrm{Z}=\mathrm{C}, \mathrm{X}=\mathrm{NEC}_{50}=0.018 \mu \mathrm{M}$ $32 X=Z=C, Y=N^{2} E_{50}=0.026 \mu M$ $33 \mathrm{X}=\mathrm{Y}=\mathrm{C}, \mathrm{Z}=\mathrm{NEC}_{50}=0.037 \mu \mathrm{M}$

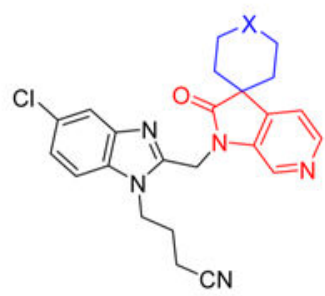

$41 \mathrm{X}=-\mathrm{NH}-\mathrm{pEC}_{50}=9.2$ $42 \mathrm{X}=-\mathrm{SO}_{2}-\mathrm{pEC}_{50}=9.06$

Figure 5.

Selected examples of RSV fusion inhibitors with spirooxindole scaffold. 
A

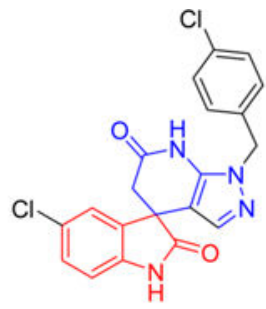

43

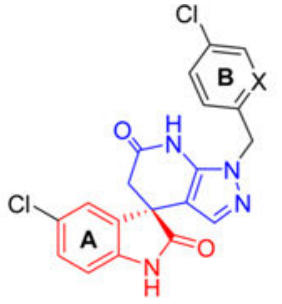

(R) $-43(\mathrm{X}=\mathrm{C})$ $(R)-44(\mathrm{X}=\mathrm{N})$

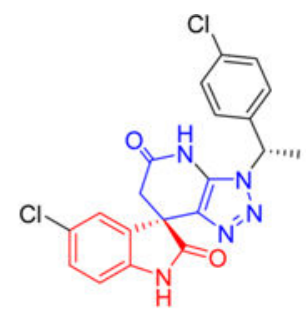

45
B

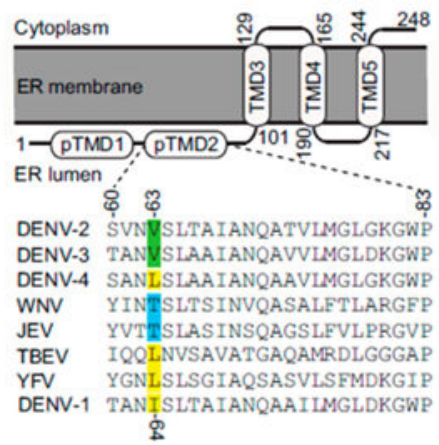

C

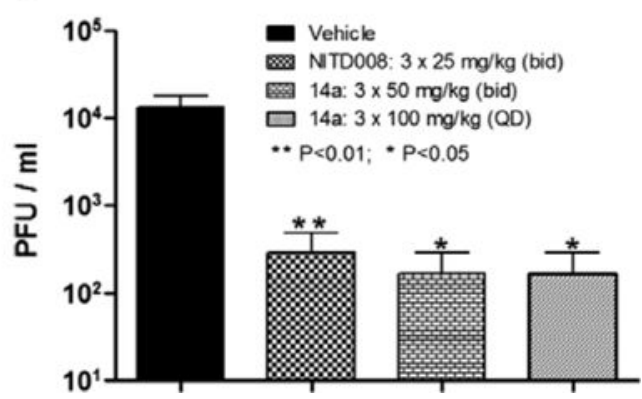

Figure 6.

(A) Selected examples of DENV NS4B inhibitors with spirooxindole scaffold. (B) Membrane topology and sequence alignment of the DENV NS4B protein. Reprinted with permission from ref 72. Copyright 2015 American Society for Microbiology Limited. (C) DENV-2 in vivo mouse efficacy of compound $(R)$-44. Reprinted with permission from ref 73. 


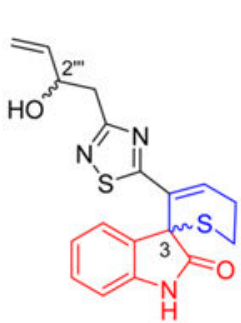

$46 \mathbf{a}\left(2^{\prime \prime \prime} S, 3 S\right)$

$46 \mathrm{~b}(2 " ') R, 3 R)$

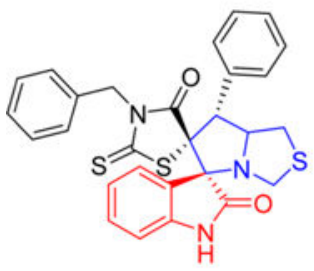

49

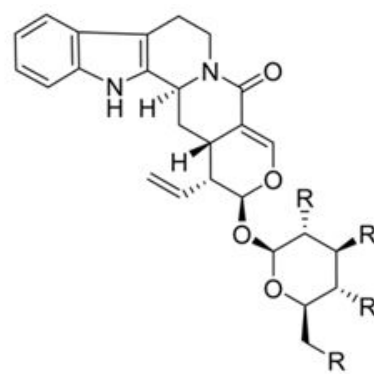

47a (Strictosamide) $\mathrm{R}=\mathrm{OH}$ 47b $\mathrm{R}=\mathrm{OCO}\left(\mathrm{CH}_{2}\right)_{2} \mathrm{COOH}$ 47c R $=\mathrm{OCOCH}_{3}$

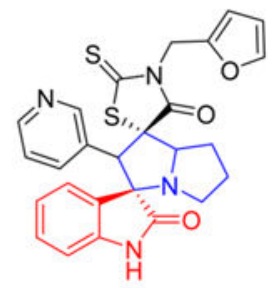

50

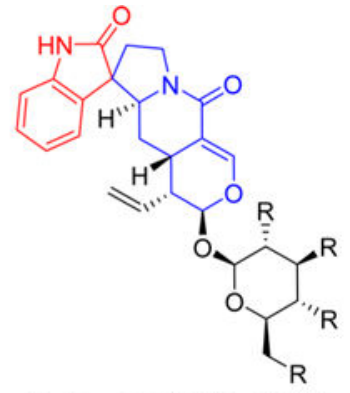

48a $\mathrm{R}=\mathrm{OCO}\left(\mathrm{CH}_{2}\right)_{2} \mathrm{COOH}$ $48 \mathrm{~b} \mathrm{R}=\mathrm{OCO}\left(\mathrm{CH}_{2}\right)_{3} \mathrm{COOH}$

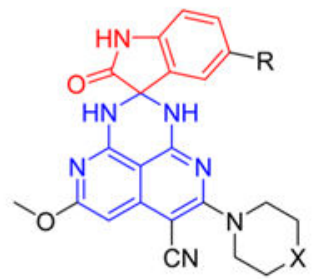

$51 \mathrm{R}=\mathrm{F}, \mathrm{X}=\mathrm{O}$

$52 \mathrm{R}=\mathrm{H}, \mathrm{X}=\mathrm{CH}$

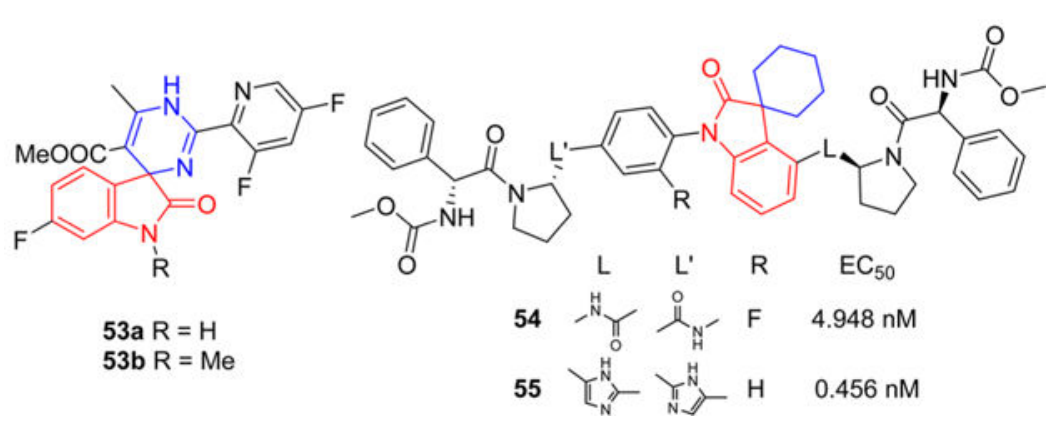

Figure 7.

Selected examples of other antiviral inhibitors with the spirooxindole scaffold. 